\title{
A Grazing Potential in the Tanga Region of Tanzania ${ }^{1}$
}

\section{E. G. VAN VOORTHUIZEN ${ }^{2}$}

\section{Pasture and Range Research Officer, Near East Foundation- U.S. AID/Government of Tanzania, Arusha, Tanzania.}

\section{Highlight}

The steady decline in the sisal market has resulted in greater emphasis on raising of livestock from sisal areas and from native rangelands in Tanzania. Livestock production in many areas of Tanzania is limited by Tsetse fly (Glossina pallidipes). However, in large blocks of land cleared for sisal production, Tsetse, which breeds in dense bushlands is now a minor problem. Proper planning for uniform utilization and maximum sustained production from rangelands are based on local experience and experimental data. In the Tanga Region of Tanzania experimental data for proper planning is lacking. This article presents the results from a range site survey and estimation of the livestock production capacity in the sisal areas of the Tanga Region. Also, the report emphasizes the need for more detailed studies.

The Tanga Region of Tanzania has approximately 13,700 square miles of high potential bushedgrassland, of which 500 were cleared for sisal production and 550 are in the Mkomazi Game Park.

Precipitation occurs from MarchMay and from October-November. The hottest months are December, January, and February and the coolest are June, July, and August. In the northern part of the region, the Usambara Mountain Range rises from the coastal belt in a northwest direction and continues as the Pare Mountains to Mt. Kilimanjaro. The Usambara serve as a watershed for the Umba River to the north and east and the Pangani River to the south and east (Fig. 1). In the southern part of the region the coastal belt is succeeded by hills, then undulating country at 1500-2000 feet elevation. The Msangasi River is the major drainage in this area.

Due to social problems related to prestige, religion, and culture, beef

\footnotetext{
${ }^{1}$ Received September 17, 1969; accepted for publication January 12 , 1970.

${ }^{2}$ The author wishes to acknowledge the assistance received from Dr. $\mathbf{L}$. White for suggestions and encouragement, and the author is grateful to the Director of Research, Tanzania and the Near East Foundation, New York, N.Y. for permission to publish.
}

production at present is almost entirely extensive with low outputs and low inputs. The traditional method of cattle management consists of grazing unenclosed common natural pasture, the cattle being tended in combined herds by members of the family and returned in the early evening to a small enclosure or "boma." As a result, the surroundings of village settlements are much overgrazed while other areas are not used. Bomas become very muddy and unhygienic and frequently cattle are not released until long after sunrise and rcturned well before sunset, thus restricting their grazing time. Research work at Kongwa, Tanzania by Owen (1968) has shown that immature Zebu cattle grazing 24 hours per day grow up to $26 \%$ faster than do animals confined to a boma at night. In a considerable area of Tanzania there is an urgent need to intensify and develop settled systems of agriculture capable of providing adequately for the increasing population. The sisal areas in Tanzania have an important role to play in this development as a grazing resource.

\section{Method}

Grass-legume plant associations were recorded and mapped along bush trails, from aerial photographs, and by airplane reconnaissance. This information was recorded on a 1:250,000 scale topographical map and later reduced to a smaller scale of $1: 1,000,000$ for publication. Using a step-point method, paced

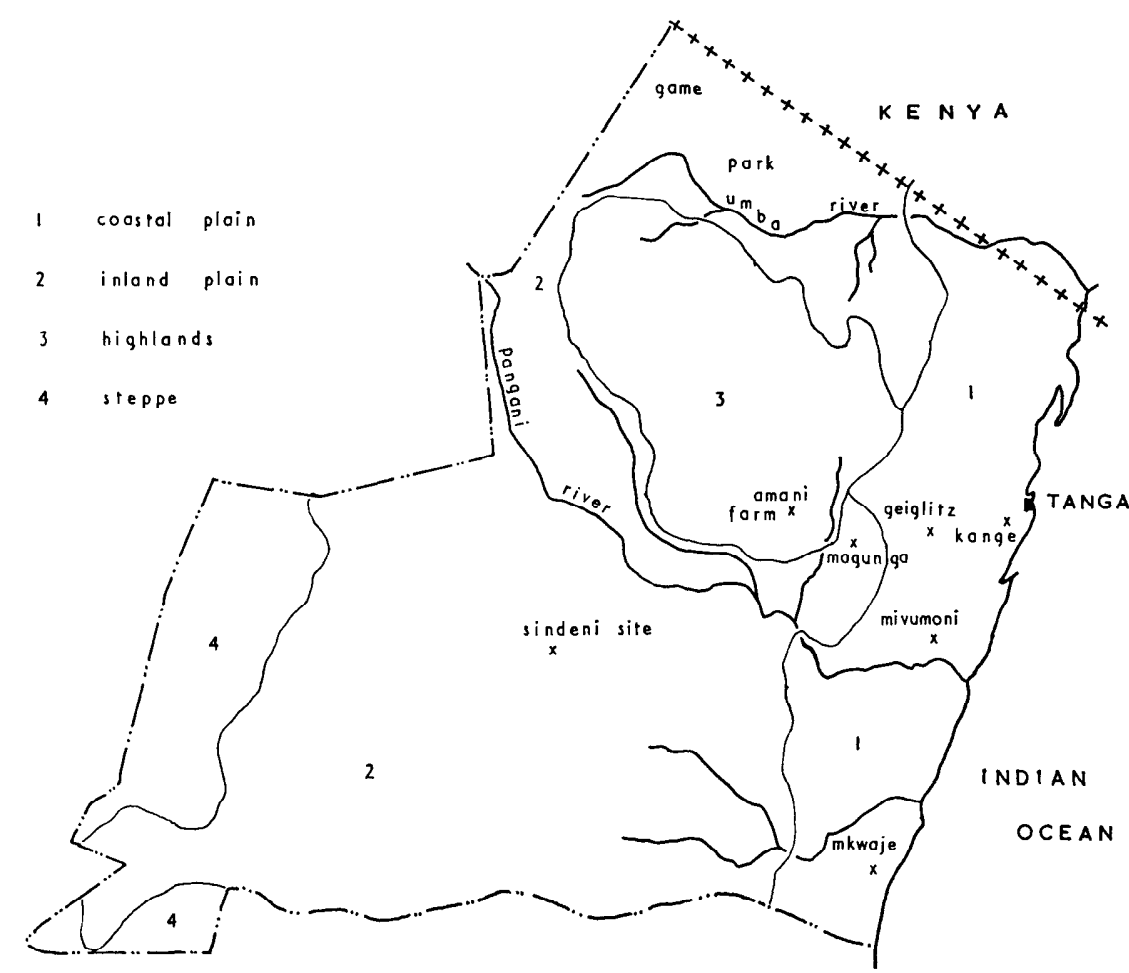

FIG. 1. Range sites in the Tanga region. 
Table 1. Composition (\%) of the major grasses on the Coastal Plain at 6 locations sampled.

\begin{tabular}{|c|c|c|c|c|c|c|}
\hline & 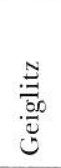 & 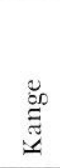 & $\begin{array}{l}\vec{\Xi} \\
\Xi \\
\Xi \\
\Xi \\
\Xi\end{array}$ & 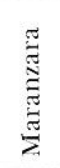 & 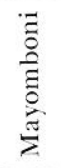 & $\begin{array}{l}\vec{\Xi} \\
\stackrel{\Xi}{\Xi} \\
\tilde{\Xi} \\
\tilde{\Xi}\end{array}$ \\
\hline Andropogon schirensis & & 4 & 9 & & 23 & 14 \\
\hline Bothriochloa glabra & 2 & & 13 & & 6 & 4 \\
\hline Cynodon dactylon & 26 & 2 & & 2 & 4 & 7 \\
\hline Digitaria mombasana & & 6 & & 7 & 4 & 3 \\
\hline Eragrostis superba & 6 & & 1 & & 3 & \\
\hline Heteropogon contortus & & 1 & 14 & 1 & & 2 \\
\hline Hyparrhenia dissoluta & & 15 & & 10 & 18 & 22 \\
\hline Hyparrhenia rufa & 19 & 11 & 9 & 7 & 14 & 14 \\
\hline Panicum infestum & & 16 & 2 & 15 & & \\
\hline Panicum maximum & 18 & & & & & 3 \\
\hline Panicum trichocladum & & & 6 & 1 & 1 & 1 \\
\hline Pennisetum polystachion & & 2 & & 6 & & 5 \\
\hline Setaria sphacelata & & 39 & & 30 & & 1 \\
\hline Other grasses & 28 & 2 & 46 & 21 & 22 & 17 \\
\hline Legumes & 1 & 2 & & & 5 & 7 \\
\hline
\end{tabular}

transects were run in representative site locations to measure the percentage composition by number. This was done by actual count and recording of the number of individuals of all forage species present. In addition, composition and range condition surveys were conducted on the Mayomboni, Gezani, Maranzara, and Amani-Marangu cattle/ coconut schemes; the Mkwaje Ranch (Amboni Sisal Estates Ltd.), the Mivumoni Ranch, and the Tanzania Sisal Corporation ranches at Magunga, Geiglitz, and Kange. The reports are on file at the Mlingano Sisal Research Station, Tanga, Tanzania.

Six transect data, representative of the coastal plain are summarized in Table 1 and six transect data, representative of the inland plain are summarized in Table 2. The Mkomazi Game Park, although a potential grazing resource is designated as a wilderness area. In order to protect the game and to preserve the park as a wilderness, the Wakwavi tribesmen with their cattle herds are being located elsewhere. The park was not surveyed.
4. The Masai Steppe-a low rainfall area.

\section{The Coastal Plain}

The Coastal Plain is bounded on the west by a distinct scarp and on east by the Indian Ocean. It is characterized by high humidity and high rainfall (40-60 inches an nually). Temperatures range from $75-90 \mathrm{~F}$. The plain extends inland about 20 miles rising to an elevation of 500 feet. The soils are loamy sands.

Hyparrhenia rufa, Setaria sphacelata, Hyparrhenia dissoluta, and Andropogon schirensis are the major grasses in the area (Table 1). Associated species include Cynodon dactylon, Panicum infestum, Digitaria mombasana, and Bothriochloa glabra. The marshy swamps along the Pangani River delta contain concentrations of Imperata cylindrica, a tough grass of low palatability, Paspalum scrobiculatum, Echinochloa haploclada, and Echinochloa pyramidalis. The abundance of naturally occurring legume forage plants such as Stylosanthes fruticosa is a significant feature of the coastal plain. Other legume plants include Vigna reticulata, Vigna dekindtiana, Teramnes labiales, Eriosema glomerata, Dolichos argenteus, Alysicarpus glumaceus, Glycine javanica, and Clitoria ternatea. These contribute

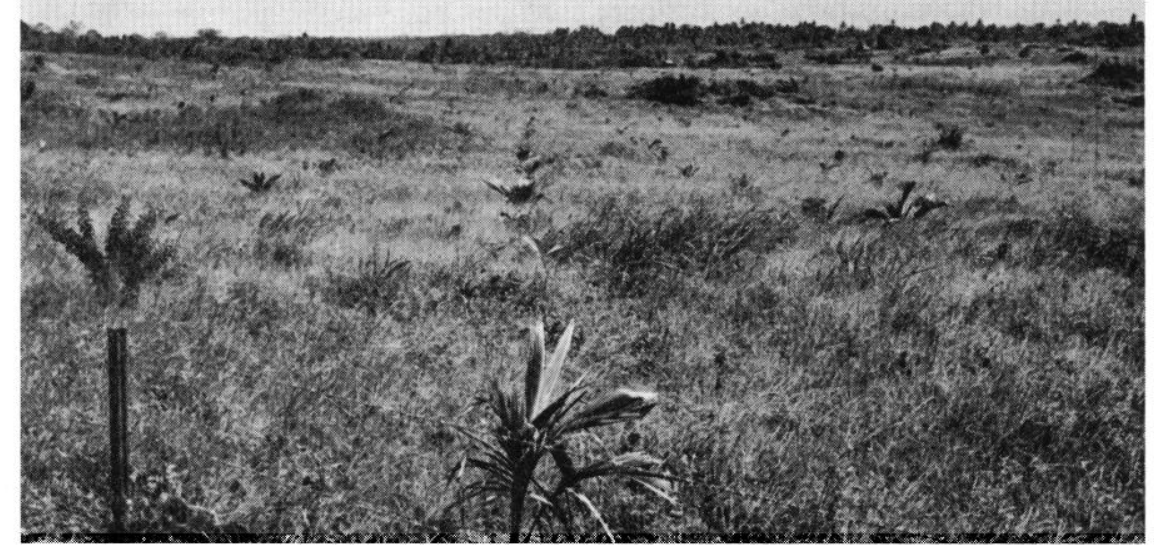

FIG. 2. Young coconut grove allowing ample forage production for cattle grazing. 
Table 2. Composition (\%) of the major grasses on the Inland Plain at 6 locations sampled.

\begin{tabular}{|c|c|c|c|c|c|c|}
\hline & 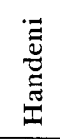 & 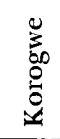 & 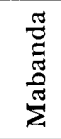 & 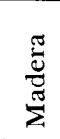 & 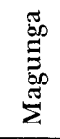 & 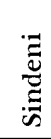 \\
\hline Bothriochloa insculpta & & & 15 & 4 & & \\
\hline Cynodon dactylon & & 14 & 3 & 19 & 9 & 2 \\
\hline Digitaria milanjiana & 11 & 12 & 2 & 22 & & \\
\hline Eragrostis superba & 3 & $\mathbf{5}$ & 12 & 4 & & \\
\hline Heteropogon contortus & & & & 2 & & \\
\hline Hyparrhenia dissoluta & 5 & & 2 & & & \\
\hline Hyparrhenia rufa & 6 & & 11 & & 19 & \\
\hline Panicum mezianum & 3 & & 6 & & & \\
\hline Panicum maximum & 16 & 2 & & 31 & 24 & 94 \\
\hline Panicum trichocladum & 3 & & & & 5 & \\
\hline Pennisetum polystachion & 1 & & & & & \\
\hline Setaria sphacelata & 12 & & & & & \\
\hline Themeda triandra & & 21 & & & & \\
\hline Other grasses & 39 & 46 & 49 & 17 & 42 & 2 \\
\hline Legumes & 1 & & & 1 & 1 & 2 \\
\hline
\end{tabular}

considerably to the improvement of the forage quality for livestock.

Near village settlements, coconut palms are often found in cultivated rows 30 feet apart allowing ample forage production for cattle grazing in coconut groves (Fig. 2). Where cultivation is not practiced, bush infestation drastically reduces forage production. Dumpalm $(H y$ phaene thebaica) is prevalent throughout the coastal plain, while Acacia zanzibarica dominates the southern part of the region.

\section{Management problems}

Bush control is a major problem in the coastal plains area, especially thicket forming Acacia species and the dumpalm. Grass burning to reduce bush density as it is practiced by the local people is only effective with an intense hot burn. This is accomplished when the grass cover is left ungrazed for at least a year to provide maximum burnable material. Although this is an economic way to reduce bush, the practice lowers the grazing capacity. With improved management and increased grazing intensity, the loss of forage from repeated burning to control bush is not justified. Mechanical methods are more feasible in controlling bush. The management of the Tanzania Sisal Corporation at Geiglitz (Stevens, 1969) has found that the initial clearing of shrub-type bush can be done effectively with a D-8 type Caterpillar tractor pulling a heavy duty Marden L-10 brush cutter at the cost of Sh.44/-(44 shillings) per acre. This must be followed up by stacking and burning using hand labor at Sh.24/- per acre. From then on the fields can be maintained with an occasional run of a farm tractor and rotary mower at a cost of Sh.4/-per acre annually. Adoption of such expensive practices requires good management to insure adequate returns on the investment.

\section{Grazing capacity}

The Hyparrhenia grass associations are not difficult to manage with proper numbers and distribution of livestock. The annual rainfall insures a continuous forage supply, although quality varies. It is indeed extremely rare when there is no rainfall recorded for any one month even during the dry seasons. Forage production from Hyparrhenia rufa in pure stands was estimated from clippings at $4400 \mathrm{lb}$. per acre. A pure stand of Setaria sphacelata yielded $3880 \mathrm{lb}$. per acre. Since there is a tremendous variability in forage production from year to year and a conservative stocking rate may mean overgrazing in successive dry years, stocking rates based on yields must be used as a guide only. It would be advisable to use utilization surveys in determining actual carrying capacity for each growing season.

At the Mkwaje Ranch, experience shows that 8 acres will carry 1 animal unit yearlong and this figure can be used as a starting point for other areas in the coastal plain.

\section{The Inland Plain}

The Inland Plain area is bounded on the west by the Masai Steppe and the Usambara Mountain Range to the north. The further inland the greater extremes in day and night temperatures and lower humidity. Rainfall becomes progressively lower moving inland to the dry and sparsely populated Masai Steppc. The avcrage annual rainfall is 25-35 inches.

The soils are a red sandy loam with Guinea grass (Panicum maximum) the dominant species (Table 2) and occasionally found in pure stands (Fig. 3). Van Rensburg (1949) reported that Guinea grass is abundant in shaded areas where it is quite robust providing an abundance of flammable material in the dry season. Also it is remarkably tolerant to burning and thrives in areas which are periodically subjected to fierce fires. It recovers quickly from burning and will become established as the dominant species where burning is practiced. Associated species in the drier areas are Cynodon dactylon, Digilaria milanjiana, Hyparrhenia rufa, and Eragrostis superba. Legume plants are not so abundant as in the higher rainfall areas but Dolichos taubertii and Glycine javanica are common. Other species such as Vigna vexil- 


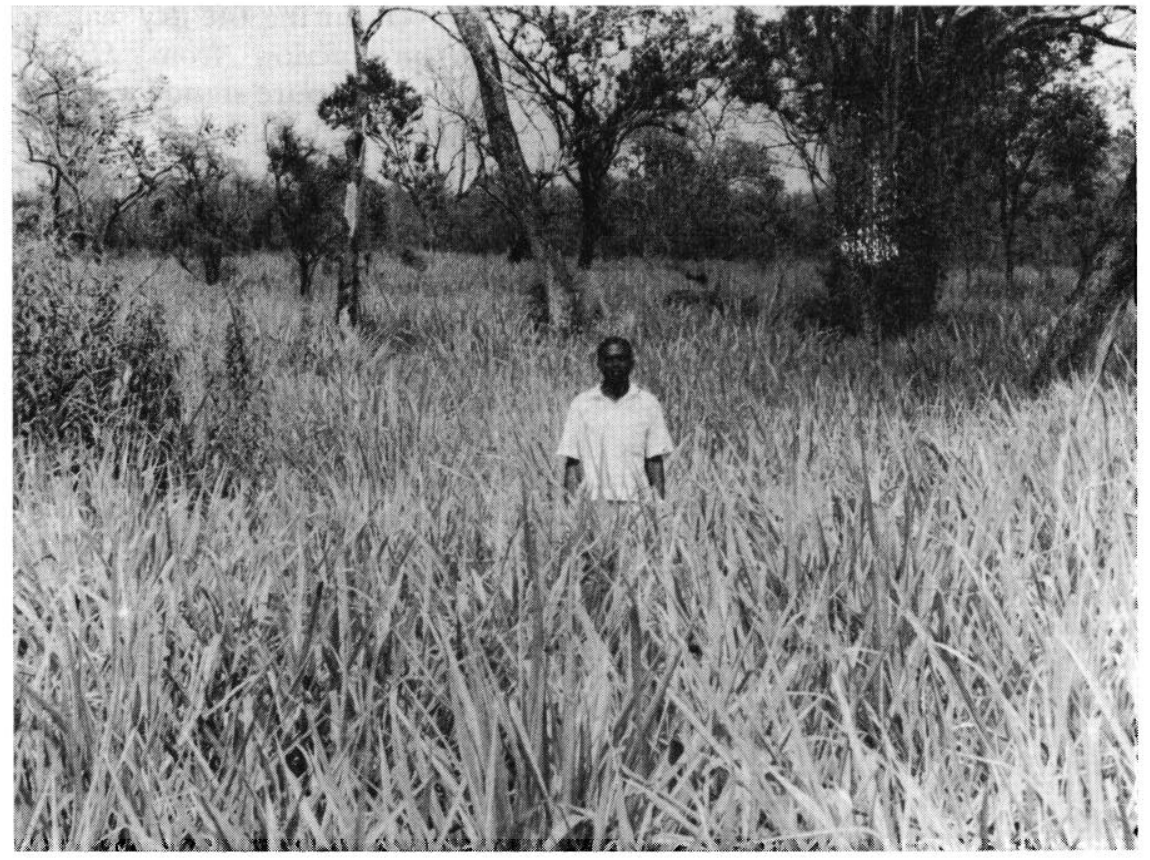

FIg. 3. Pure stand of Guinea grass at the Sindeni site location.

lata, Vigna fragrans, and Dolichos argenteus are less frequently found.

One aspect which is often overlooked is the utilization of indigenous leguminous species and other browse trees by stock particularly in the semi-arid regions. Van Rensburg (1948) lists some of the more important species indigenous to East Africa many of which occur in the inland plain. Acacia albida, A. benthamii, $A$. spirocarpa, and others yield heavily of leaves and pods which are relished by stock during the dry season.

\section{Management problems}

Most sisal estates have developed in the Pangani River Basin and near transportation routes for easy access to the coast. The undeveloped wooded areas are difficult to clear because of the larger size bush-type and frequent thickets. Also, the production of livestock is hindered by the increased Tsetse fly problem, which may explain the low cattle populations in the area. Prophylactic drugs would be required to maintain proper animal health to reduce losses from Tsetse. Tsetse fly breeds in dense bush cover, and where areas have been cleared of bush, the incidence of Tsetse is markedly reduced. Bush control therefore must be considered a major management concern (Fig. 4).

Naveh (1966) cautions that we do not know enough about the importance of trees and shrubs possibly in recycling of nutrients from the subsoil and that indiscriminate bush eradication must be avoided. The object of the removal of undesirable plants must remain the creation of a stable bush-grass ecosystem. One solution will be to confine bush clearing to removal of thickets.

Bentley (1963) claims that handclearing methods in control of bush are adapted to the tree-shrub types, but it is too expensive for thicket types. Mechanical treatments are the only proven means for opening up thicket types that are too dense for hand clearing or for successful burning. For mechanical clearing of excessive tree growth two operations are needed. One to chain the area, requiring two D-8 size tractors and followed by a D-8 pulling a Marden brush cutter. This is needed because during chaining the smaller thorntrees bend under the chain and then spring back to their original position. Considerable hand clearing and burning must then take place to make the area suitable for grazing. This requires an initial outlay of approximately Sh.110/- per acre to become operational. The present low level of returns from livestock restricts such expenditures unless much improved management can be attained.

\section{Grazing capacity}

A substantial increase in forage production results from clearing Guinea grass-wooded areas. Hopkinson (1969) reports that Guinea

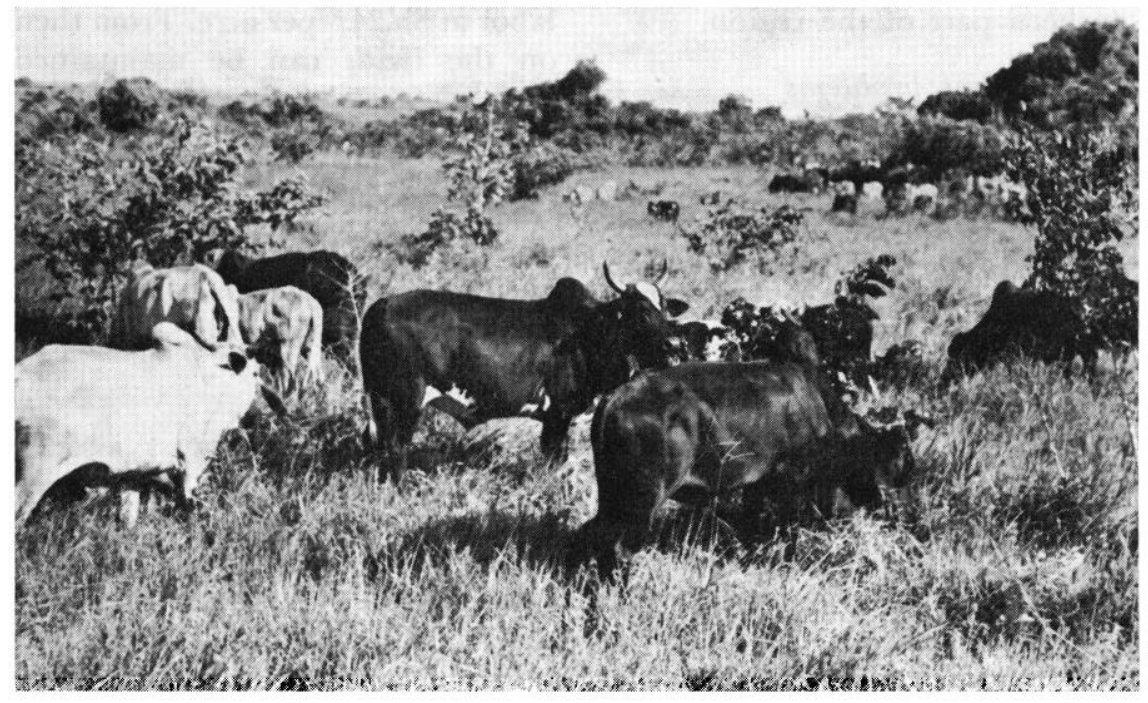

Fig. 4. Bush control must be considered a major concern. 
grass can yield as much as 11,700 lb. per acre. The high forage production is the result of good soil fertility and better water holding structure of the soil. The cleared areas thus have a higher stocking rate than the coastal plain. At Magunga with good management it is possible to carry 1 animal unit yearlong on 6 acres and this is acceptable for the areas that once were cleared for sisal production. To bring the undeveloped wooded areas up to this carrying capacity, bush must be controlled.

One method of appraising the economics of bushcontrol is to consider the total cost of the initial and follow-up control work on a land unit over a period of years. Bentley (1963) assumes that if the investment is amortized over a 20 -ycar period at an interest rate of four to five percent, the net return each year must equal about ten percent of the initial investment. Thus, at a stocking rate of 6 acres, the initial investment in bush control is approximately Sh.660/-per animal unit. Kidner (1965) in studying beef production from feeding trials using different breeds of cattle, indicates that indigenous Zebu cattle in good condition have a low average live-weight gain potential of about $0.75 \mathrm{lb}$. per day. In terms of shillings and cents, 6 acres will realize a return of Sh.164/- per year at present price levels of Sh.0.60/per lb. Although these costs justify the initial outlay of capital investment, bush clearing will remain a restriction for livestock development as long as costs for operation and maintenance of mechanical equipment continue to rise without subsequent recoveries from beef production.

\section{The Usambara Highland}

The Usambara IIighland has a cooler climate than the other range sites. Elevation ranges from 20006000 feet with a rainfall between 56 to more than 90 inches annually. The soils are a red loamy clay.

The Usambara Highland does not qualify as rangeland but is suit-

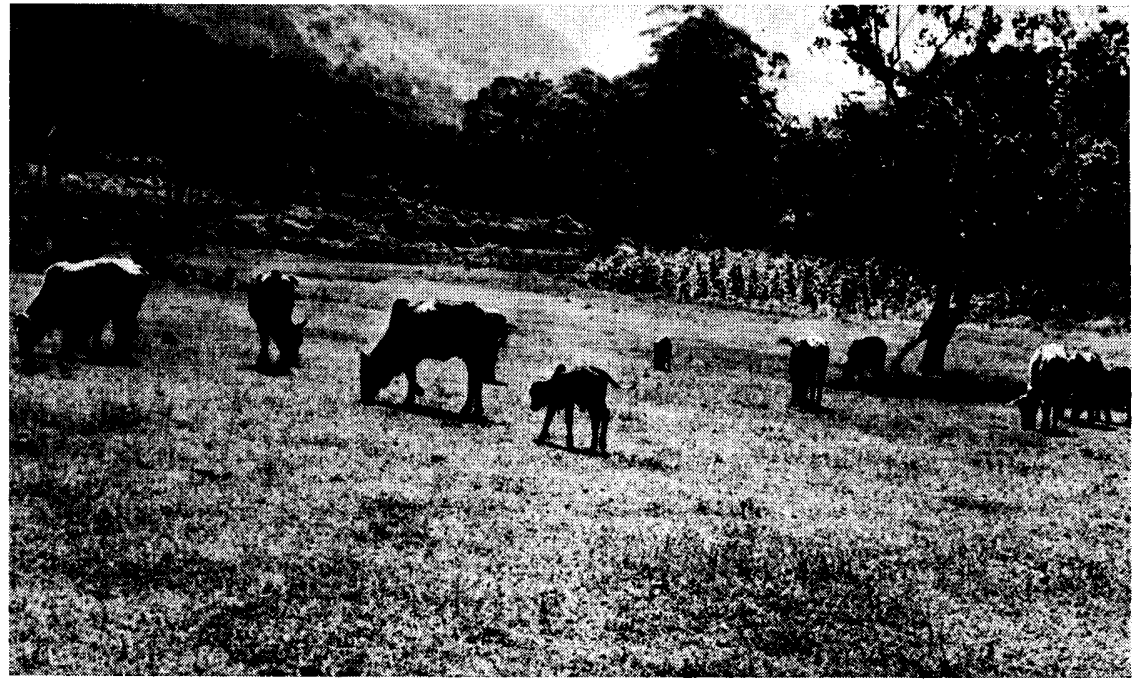

FIG. 5. The Usambara highland is suitable for intensive livestock management.

able for intense specialized livestock management (Fig. 5). At the higher elevations with cooler temperatures, steeper slopes, shallow soils, and an increased amount of rainfall, Paspalum dilatatum, Melinis minutiflora, Pennisetum purpureum, and Pennisetum clandistinum, a creeping rhizomatous sodforming grass, are the main forage plants. In the lower Usambaras Panicum maximum, Cynodon dactylon, Digitaria scalarum, and Paspalum scrobiculatum form the main perennial associations. In moist locations there are some robust growing species such as Pennisetum trachyphyllum, Agrostis schimperiana, and Festuca gigantea. The legumes Glycine javanica, Clitoria ternatea, Vigna fragrans, and Dolichos taubertii appear in good concentrations.

\section{Management problems}

The undulating topography of the hillsides accentuates a danger of soil erosion. The encroachment of cultivation on grazing lands with indiscriminate bush clearing for the cultivation of rowcrops is increasing the danger of soil losses unless conservation is practiced with terracing and maintaining a soil cover.

The Tanga Region Extension Service is teaching the farmers in the Usambara hills to plant Guatamala grass (Tripsacum laxum) for soil conservation with their tea plantings (Ministry of Agriculture, 1968). Where cultivation is not practiced the sodforming creeping grasses are desired for grazing. Since the erosion threat becomes pronounced with close grazing it is of vital importance that stocking rates are properly determined and management is practiced.

\section{Grazing capacity}

With the possibility of very productive seeded pastures and plantings of large fodder-type grasses and legumes, the grazing areas can become suitable for highly specialized livestock operations such as dairy farming or fattening of young stock. At Amani, Kikuyu grass (Pennisetum clandistinum) is providing excellent grazing and it has been reported earlier, (Eichinger, 1914) that in Amani seven head of milking cattle were kept on ten acres of Paspalum dilatatum pastures and with never a feed shortage.

\section{The Masai Steppe}

The Masai Steppe is a large area that covers most of central and northwest Tanzania. Lower rainfall, 18-25 inches, and vegetative characteristics bring the steppe into a different site category. It will not be discussed in this article for the Tanga region. 


\section{Conclusions}

Sisal production is now being restricted and livestock keeping is becoming increasingly important. Most sisal growers feel reluctant to engage in such a new and different enterprise and more detailed information is needed that should form the basis for the planning and utilization of this vast grazing resource. With an estimate of the grazing capacity the viability of ranch operations on sisal lands and on native lands can be better evaluated for needed water developments, fencing, bush control, reseeding, and livestock programs. Four range sites were delineated in the Tanga Region of Tanzania. Their estimated capacities varied from 1 animal unit yearlong on 8 acres to 1 on less than 2 acres. Lower grazing capacities occur on the Masai Steppe, but is not covered in this article. Capital investments for im- provements can be justified where the estimated grazing capacities can can be achieved or present conditions markedly increased with intensive management. When cattle keeping in these areas is recognized as an integral part of range management it can become a highly profitable enterprise. With a potential of 500 square miles of cleared sisal land beef production in the Tanga Region of Tanzania promises to be a successful and a very viable undertaking which is catering to an even growing market in East Africa.

\section{Literature Cited}

Bentley, J. R. 1963. Bush control in Kenya. Ministry Agric. Kenya U.S. AID, Nairobi, Kenya.

Eichinger, A. 1914. Die Weide und Futterverhaltnisse von West Usambara Beiheft zum Pflanzen No. 2:5.

Hopkinson, D. 1969. The potential of some pasture species in the sisal areas of the Tanga Region of Tanzania. (Unpublished manuscript) Mlingano Sisal Research Station, Tanga, Tanzania.

KIDNER, E. M. 1965. Beef production, Part 2. E. Afr. Agr. F.J. 32:9195.

Ministry of Agriculture. 1968. Annual report. Tanga Region Extension Service. Dar es Salaam, Tanzania.

Naven, Z. 1966. The need for integrated range research in East Africa. Trop. Agr. Trin. 43:95-97.

OwEN, M. A. 1968. Studies with beef steers on the Kongwa plain, Central Tanzania. Trop. Agr. Trin. 45:159171.

Stevens, B. A. 1969. Livestock manager, Tanzania Sisal Corporation. (Personal communication.)

Van Rensburg, H. J. 1948. Notes on fodder and pasture plants in Tanganyika Territory. E. Afr. Agr. F. J. 13:149-152.

Van Rensburg, H. J. 1948. Notes on some browse plants. E. Afr. Agr. F. J. 13:164-166. 